\title{
Socio-economic Consequences of Sand Mining along the Victory River in Port Harcourt, Nigeria
}

\author{
Simeipiri Wenike Johnbull ${ }^{1}$ and Ibama Brown ${ }^{1^{\star}}$ \\ ${ }^{1}$ Department of Urban and Regional Planning, Rivers State University, Port Harcourt, Nigeria.
}

Authors' contributions

This work was carried out in collaboration between both authors. Author SWJ designed the study, performed the statistical analysis. Author IB wrote the protocol, the first draft of the manuscript, managed the analyses of the study. Author IB managed the literature searches. Both authors read and approved the final manuscript.

Article Information

DOI: $10.9734 / \mathrm{AJEE} / 2017 / 34087$

Editor(s):

(1) Wen-Cheng Liu, Department of Civil and Disaster Prevention Engineering, National United University, Taiwan.

Reviewers:

(1) Sanchayan Mukherjee, Kalyani Government Engineering College, India.

(2) Kadiri Umar Afegbua, Centre for Geodesy and Geodynamics, Nigeria. Complete Peer review History: http://www.sciencedomain.org/review-history/19793

Original Research Article

Received $12^{\text {th }}$ May 2017

Accepted $21^{\text {st }}$ June 2017

Published $1^{\text {st }}$ July 2017

\begin{abstract}
Rivers generally have been source of livelihood for several persons in both developed and developing countries, and the rivers have been exploited without recourse to the consequences of this action by those involved. The aim of this research is to assess the social and economic consequences of sand mining on communities along the Victory River. The objectives are to: examine residents' perception, identify the impacts of sand mining in their domain and propose mitigation measures for moderate and major negative impacts and enhancement measures for positive impacts of sand mining. Hazards and effects management process (HEMP) was used identify the impacts of sand mining on the communities and propose mitigation measures for moderate and major negative impacts and enhancement measures for positive ones. The study adopted multistage sampling technique by identifying all the communities along the Victory River and purposively four (4) communities were selected for the study. Mixed methods were used to collect data with one-hundred and twenty-three (123) structured questionnaires and key informant interviews. The study found that continuous river sand mining had altered the river courses and increased the width and depth of the Victory River. Livelihood chain of the people have been distorted leading to diminished purchasing power, increased poverty level and other associated
\end{abstract}


social vices. There were also identified socio-economic benefits like employment and revenue generation for the communities. The study recommends that: river channel cross sections should be benchmarked using aerial photographs and periodic hydrographic survey, effective social management plan and enhancement measures be taken, enforcement of relevant laws to control the activities of sand miners and their host communities alike.

Keywords: Costs; lessons; livelihood; natural resource mining; Port Harcourt; Victory River.

\section{INTRODUCTION}

Nature in its benevolence has clearly made it manifest that rivers are part of the life supporting systems it has offered mankind. Over time human activities have altered the pattern of river flow by damming river courses and overexploit both non-renewable and renewable natural resources found within the river like sand and gravel and in return use rivers as waste dumpsites. These actions portend threat to the river ecosystem and other marine species including humans who depend on these rivers as their source of livelihood.

Sand is a natural resource, and a consequence of natural process of weathering which is a key constituent in the construction and allied industries are found in abundance in most oceans, rivers, streams, flood plains and hills.

The increased demand for sand has placed rivers where sand is found vulnerable to the vagaries of anthropogenic activities. Among which uncontrolled and continuous sand mining is the most disastrous because it portends great threat to the existing bionetwork and waterways [1].

The dynamics of emerging urbanization with its attendant growth in population, settlements, industrialization and associated changes have also contributed in the uncontrolled and overexploitation of sand around instream locations. [2] assert that uncontrolled in-stream mining of sand is fallout of: effortlessly available social housing scheme, swift economic development and improved foreign exchange earnings of a country.

Natural resource extraction in some developing countries especially in the Global North, has over the years been a knotty issue because of the seemingly helpless situation and inequality in implementation of the laws governing the practice subsist. This situation had pitched owners of these resources against the exploiters of the resources and the government.
The act and art of sand mining in the opinion and field experiences of the researcher involves the mining of sand over open pits which most times occurs around inland dunes, river beds and beaches. The actions of humans had impeded the functioning of river systems. Sand based on its importance is a very useful and easily available construction material like gravel and clay but has fast depletion rate and a stunted replenishing time.

Rivers unlike land are usually the most evolving ecosystem due to its recharging system and prominence as a means of sustenance to marine flora and fauna.

Sand is a low-priced readily available natural resource, a product of weathering, with constituent parts of other minerals and rock mostly found in deserts and seashores [3,4]. River sand basically are sand extracted from the banks and beds of rivers. But the practice has been encumbered with rudimentary and unsustainable techniques in its mining which has led to serious ecological conditions of the ecosystem of the mining sites and adjoining environment. This has resulted in inequity and misplaced priority of the miners and owners of those sites which causes more harm than good to all concerned.

River sand as the name implies is a natural resource found in abundance within and around some coastal regions in the world but the processes and techniques of extraction have been given little considerations in most developing countries in the Global South. The attention is required especially in the recharge time, the environmental, social and economic challenges and the reference state. The emphasis most times is placed on the income streams it generates, the tangible accruals derivable from this resource and other short term benefits.

The reference state as averred by [5] is key to river sand mining because it establishes the minimum acceptable natural and physical 
conditions the river course can handle, determine the location, quantity and frequency to mine sand. However, it is quite tasking to determine this reference state because the effects of sand mining can be reduced through fluvial process thereby downplaying the emphasis on the reference state at a given point in time.

\subsection{Global Sand Mining Trends}

According to [6] there is intensive world-wide mining of sand which is focussed more in unindustrialized and some industrialized countries where sand is processed into important raw material for construction and other related industries. This has created the challenge of sustainable sand extraction which would have had little or no damage to the environment but the contrary is the situation in developing countries.

The United States of America leads the pack of industrialized nations in sand extraction as the largest producer and user of sand [7]. The United States as a developed economy has brought to the barest minimum the menace and associated ecological concerns generated by intensive sand extraction due to the strict enforcement and compliance of laws governing the extraction of natural resource like sand. Although this cannot be said for India, Kenya and Nigeria who are at the fore front of emerging economies with established cases of intensive sand mining which has some form of negative environmental consequences.

Sand is one of the readily available construction based raw material in India and its extraction has been weakly controlled by extant mining laws and this phenomenon has led to the emergence of uncontrolled mining of sand and damage to the environment. An identified trigger for intensive sand extraction is the thriving construction industries which drives development. This activity has caused some rivers to become vulnerable to adverse externalities of the environment [8].

\subsection{Sand Extraction in Africa}

Some emerging economies of the Global South especially in Africa tend to concentrate developments more in urban centres. This has led to intensive sand mining to meet the demand for sand by the construction sector for developments at the expense of infrastructural deficit of the rural areas where the sand is mined.
As a readily available construction material, [4] asserts that sand is the foremost construction raw material that prevail in most African societies like Kenya because of the availability of sand sources within and around some communities. Despite the pecuniary accruals occasioned by sand mining, there are some adversative consequences trailing this activity in the Kenyan environment as it has brought a mix of both official and unapproved sand miners who besiege and forage around recreational centres, dunes, beaches and riverbanks.

[9] asserts that in some parts of northern Nigeria, communities and land owners who are stakeholders: fisher folks, farmers and others whose sources of livelihood revolve around the quarries grant mining rights to prospective sand miners without recourse to the environmental consequences and imminent ecological disaster. The government agencies saddled with the responsibility of implanting development control has shown ineptitude and this has resulted to intensive uncontrolled sand mining around the quarries leading to ecosystem imbalance, depletion of the sand and other derivatives associated with its extraction and serious environment.

The adverse outcome of sand mining far outweighs the positive impact because in most cases arable lands are dug up to mine sand. This leaves the people with limited access to sources of livelihood [10].

In South Africa [11] assert that the process of granting mining permit to extract sand and gravel is very strict even though it is viewed as income stream source. There is a caveat that it has catastrophic ecological consequences because the entire process displaces the flora and fauna within and distorts the ecosystem balance. This is an indication that there is conscious effort to control and regulate the activities of prospective sand miners.

In the rendering of [12] sand mining was not a popular activity in Harare, Zimbabwe until 2009 when the pace of construction activities revved up with the commencement of infrastructural development. With this development cooperatives were formed to seek permits from the Environmental Management Authority for sand extraction and haulage for pecuniary gains which had improved the social and economic status of those engaged in the activities. 
According to [13] the economy of Botswana thrives mainly from natural resource extraction which include: Gold, diamond, nickel, gravel and sand which accounts for one-third of the country's Gross Domestic Product. On the other hand, this has buoyed the economy greatly due to compliance and strict enforcement of extant mining laws and proper control of mining activities by the relevant authorities in charge.

In a bid to exercise its regulatory powers over the activities of miners and practice of natural resource extraction, the government of Botswana enacted the Natural Policy on Natural Resources Conservation and Development in 1990 to protect the fragile ecosystem around mining sites. This policy made it mandatory for prospective miners to get permit from the relevant authority and must show evidence of detailed technique for extraction in addition to Environmental Impact Assessment (EIA) and Environmental Management Plan (EMP). The idea behind these conditions is to encourage sustainable natural resource extraction within the environment by all parties involved.

\subsection{Sand Mining in the Study Area}

The study area comprises of four (4) major riparian communities situate along the shoreline of the Victory river and falls within $500 \mathrm{~m}$ radius impact band of river sand mining sites as selected. The practice of sand mining in the study area is not less than 15 years old, but the intensity of the extraction and its resultant consequence has left the communities susceptible to the vagaries of the miners and government which cannot be solved in the next 30 years to come. By the physical assessment of these communities, they are populated mostly by the active age cohorts who are supposed to be at the peak of productive life cycle. Yet they have not been constructively engaged in this process. Myriads of activities have been associated with this unsustainable practice ranging from the peoples skewed perception of the temporary economic and social accruals got from sand mining, to the distortion of the ecosystem and livelihood chain which is a major challenge for survival of these communities. The government has not effectively monitored the activities of these miners who do contrary to approved conditions of operations in brazen connivance with some obscured members of these communities. And the communities have not contributed towards sustainable natural resource extraction in this circumstance because they give blind approval to mining companies without reference to provisos of extant laws. This is fallout of the pecuniary accruals to both the owner and the user alike

\subsection{Impact of Sand Mining}

Sand mining is a very crucial component of natural resource extraction and it has consequences that are positive and negative.

\subsection{Positive Impacts of Sand Extraction}

The practice of natural resource extraction is a global phenomenon which [14] asserts that it involves income streams along all strata of the value chain; from the extraction to haulage and end users.

The incremental nature of global population has resulted in soaring demand for natural resource extraction like sand and its allied derivatives due to its potential for pecuniary benefits for the owner and the user alike.

The extraction of sand as a natural resource has contributed to the enhancement of several cityscapes globally. There is no doubt that extracted sand and its allied derivatives are major constituents of any form of development from infrastructure to physical development within the environment in most developed and some developing economies (Chimbodza 2012 cited in $[15,6,1]$.

Riverbeds and waterways are cleared of silts and sediments in the process of extraction of sand and its allied derivatives. This also helps to grade waterways, control the degree of inundation and stabilize the rivers. This has made some waterways more navigable and encourage inland water transport system, develop tourism potentials, generate revenue for governments and communities, create employment and has reduced the pressure to engage in social vices and alleviate economic hardship $[4,9]$.

\subsection{Negative Impacts of Sand Extraction}

Amid the positive impacts of natural resource extraction that thrives some economies globally, there are some adverse consequences of this process. 


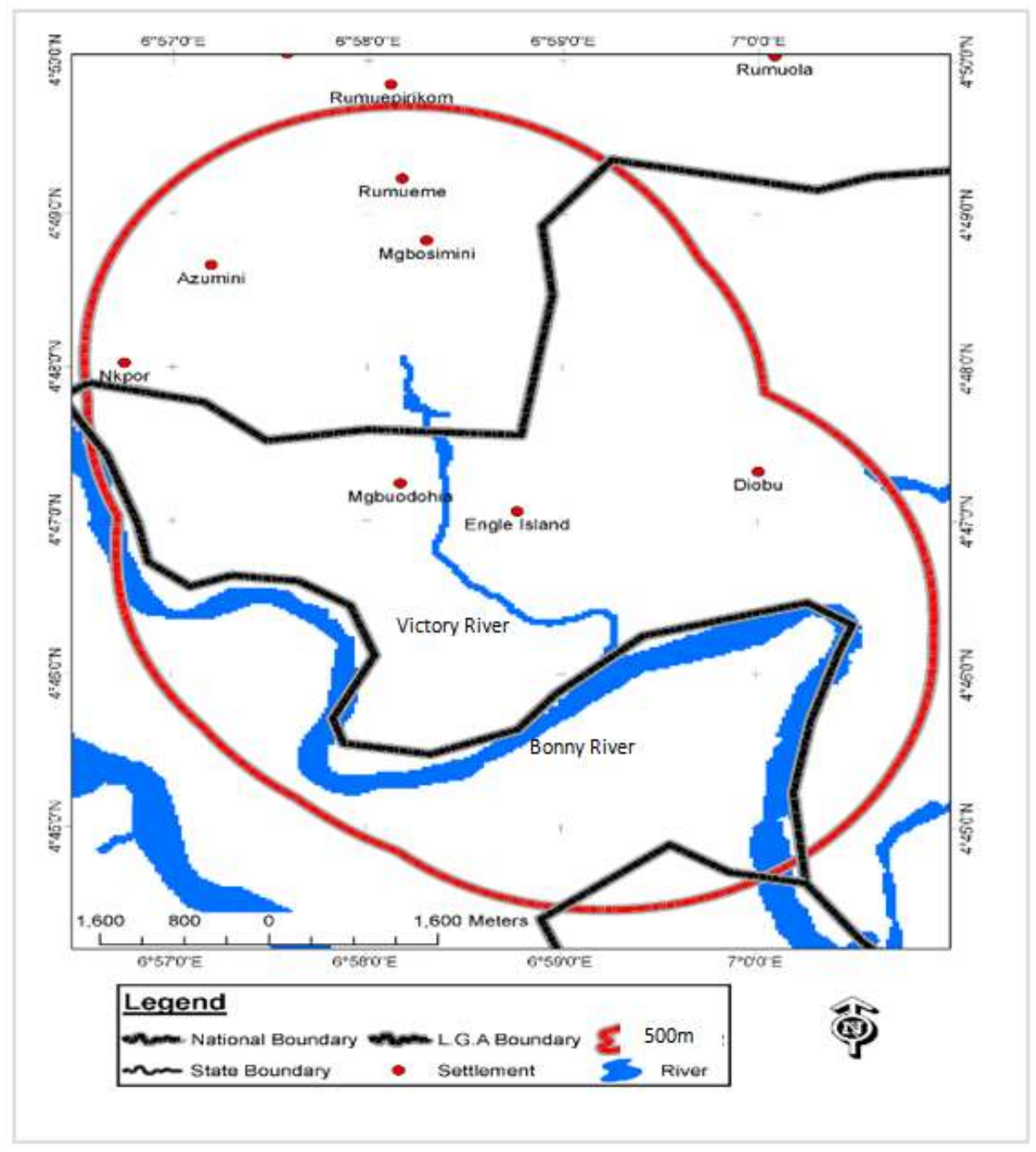

Map of the study area showing $500 \mathrm{~m}$ impact band

Source: GIS lab, Rivers State University, 2016

Channel incision done through head cutting and hungry water techniques are mostly used for instream sand extraction. It entails skimming of bars and unswerving excavation of pits leading to the distortion of the ecosystem, biodiversity loss, displacement and destruction of habitat for marine species of flora and fauna with eventual degradation of the environment, loss of potential tourist attractions and attendant revenue accruals $[7,1]$.

Furthermore, $[16,7,1]$ assert that continuous instream mining of sand and its allied derivatives increases the velocity of the river and damages the river banks. This further degenerates into upstream and downstream erosion, alters the river course direction and reduces the alluvial and groundwater tables and spans across the shoreline running into several kilometres.

In the rendering of $[17,4]$ sand mining in some developing economies have resulted into some precarious trends. This includes insecurity along waterways, incremental loss of potable water, poor water quality, formation of suspended particulates and health challenges occasioned by spills from plants and heavy duty machinery used for sand mining and other activities.

There is a major negative impact of sand and its derivatives extraction within the study area which is the emergence and institutionalization of urban and rural gangs within the neighbourhoods. This phenomenon has its spread effect on the youths 
with such polarity that there is fight for territorial control between rival gangs around the sand mining sites within the study area.

\subsection{Control of Natural Resource Mining in Nigeria}

In contemporary Nigeria, the control of natural resource extraction like sand and its derivatives is governed by several laws which has not been enforced but has been given priority lip service by policy makers, government regulatory agencies, communities and individuals.

It is worthy of note that the Federal Ministry of Environment in Nigeria oversees the protection of the Environment and conserve Natural Resources found in the country, as contained in Decree 58 of 1998 and 59 of 1992. The Federal Ministry of Environment from its inception tends to control, monitor and reduce wastes from the industries which includes the pollution of the environment. The statutory documents currently in place with semblance of development control in Nigeria and Rivers State are:

i. The Rivers State Urban Development and Physical Planning Law No. 6 of 2003;

ii. S.1.15-National Environmental Protection (Management of solid and Hazardous Wastes) Regulations of 1991.

iii. Environmental Impact Assessment Decree No. 86 of 1992.

iv. The Nigerian Urban and Regional Planning Decree 88 of 1992

v. National Inland Waterway Authority Law No. 13 of 1997.

These laws are put to regulate activities associated with natural resource extraction like sand and its derivatives within the Nigerian environment but these laws are not enforced by the relevant agencies of government.

\subsection{Statement of the Problem}

The Victory River has been overwhelmed by the activities of sand miners over the years who have the intent of satisfying the construction need of developers within and around the Port Harcourt metropolis. Based on this there is nonstop sand extraction without consideration to the consequences on the environment. This has degenerated into plethora of dire ecological consequences which include: Distortion of livelihood chain of communities, distortion of ecosystem, destruction of the marine fauna and flora, destruction of access roads within the mining sites and the incremental deepening and widening of the Victory River.

\subsection{Research Aim}

The aim of this research is to assess the social and economic consequences of sand mining on communities along the Victory River course.

\subsection{Objectives}

The objectives are to:

1. Examine residents' perception on the effect of sand mining in their domain;

2. Identify the impacts of sand mining on the communities; and

3. Propose mitigation measures for moderate and major negative impacts and enhancement measures for positive ones.

\section{METHODOLOGY}

\subsection{Research Design}

The study adopted the multistage sampling technique: Identification of all the potential river sand mining locations along the Victory River, selection of the communities that falls within $500 \mathrm{~m}$ radius impact band from the center of the Victory River. Four (4) communities were purposively selected and one-hundred and twenty-three (123) questionnaires were distributed. Criteria for selection was based on proximity to the river and intensity of sand mining around the community and questionnaire distribution was based on community population. Respondents were stratified to heads of households, community chiefs (key informants), members of community development committees (CDCs), sand miners, sand sellers and sand transporters.

Table 1. Questionnaire distribution in the study area

\begin{tabular}{lll}
\hline S/N & Community & Questionnaire distributed \\
\hline 1 & Mgbuodohia & 33 \\
2 & Nkpor & 21 \\
3 & Mgbuosimini & 28 \\
4 & Eagle Island & 41 \\
& Total & 123 \\
\hline \multicolumn{3}{c}{ Source: Authors' field survey, 2016 }
\end{tabular}

Primary and secondary data were collected. Primary data sources were; The questionnaire, photographs and participant observation. Results were interpreted with descriptive statistics like 
charts, tables and percentages. Hazards and effects management process (HEMP) was used to identify and classify the effects of the possible outcome of the sand mining. Enhancement and mitigation measures like the social management plan were formulated.

\section{FINDINGS AND DISCUSSION}

\subsection{Findings}

The research findings are presented as follows:

i. Respondents rated sand mining in their domain as very beneficial;

ii. There were identified benefits and hazards associated with sand mining;

iii. There were social and economic consequences of sand mining;

iv. Extant laws governing natural resource extraction, development control, waterways protection and physical planning was flagrantly disregarded;

v. There was distortion of ecosystem leading to displacement, destruction of flora and fauna and subsequent of loss of livelihood sources.

\subsection{Discussion}

\subsubsection{Respondents perception on the effects of sand mining}

The perception of the respondents as rated from responses indicate that the presence of river and sand miners has been very beneficial to the communities. The reason for this response was further elaborated in the Table 2 and Plates 1, 2 and 3 where the specific benefits were itemised as thus.

Table 2. Respondents rating of the sand mining in the study area

\begin{tabular}{lll}
\hline S/N & Rating & $\%$ \\
\hline 1 & Very beneficial & 63 \\
2 & Beneficial & 19 \\
3 & Not Certain & 2 \\
4 & Harmful & 13 \\
5 & Very harmful & 3 \\
& Total & 100 \\
\hline & Source: Authors' field survey, 2016
\end{tabular}

The respondents have indicated that their perception of sand was hinged on the tangible benefits accruing to them. Most of the respondents benefitted from the trickle-down effect of the accruals from sand mining in the study area because as the extraction progressed there were ancillary services rendered by some of the respondents and boost of the local economy, improved income streams and the like.

Table 3. Community views of the impacts of sand mining

\begin{tabular}{lll}
\hline S/N & Community Views & $\%$ \\
\hline 1 & $\begin{array}{l}\text { Development of neighbourhood } \\
\text { infrastructure. }\end{array}$ & 18.5 \\
2 & $\begin{array}{l}\text { Income stream for community } \\
\text { Development Committee (CDC) }\end{array}$ & 61 \\
3 & $\begin{array}{l}\text { Cheap construction sand } \\
\text { available for community members }\end{array}$ & 12.6 \\
4 & $\begin{array}{l}\text { Artificial ponds for livestock } \\
\text { watering. }\end{array}$ & 1.6 \\
5 & $\begin{array}{l}\text { Decrease in siltation of riverbeds } \\
\text { Total }\end{array}$ & 9.5 \\
& Source: Author's Field Survey, 2016 \\
\hline \multirow{2}{*}{} &
\end{tabular}

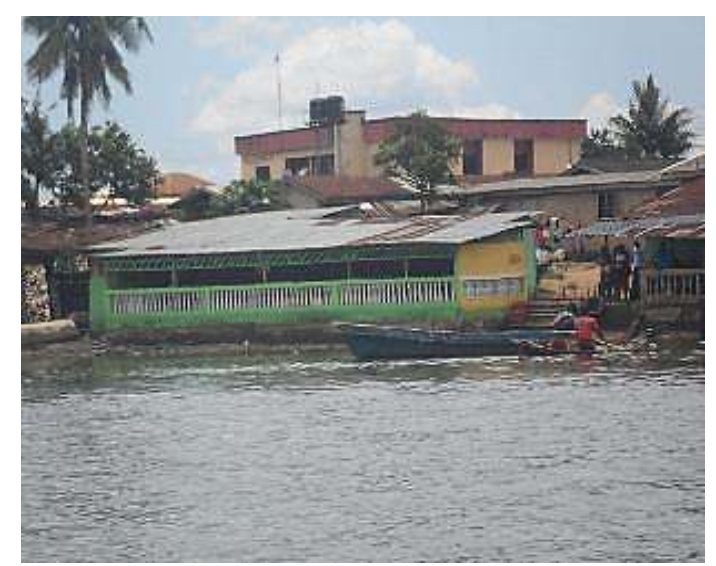

Plate 1. Showing a sea front relaxation spot in the study area

Source: Authors' field survey, 2016

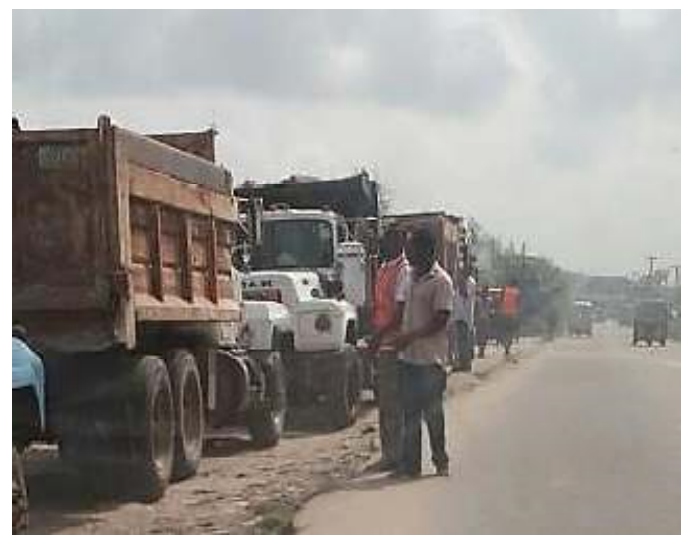

Plate 2. Showing community members in reflective vests collecting tolls

Source: Authors' field survey, 2016 


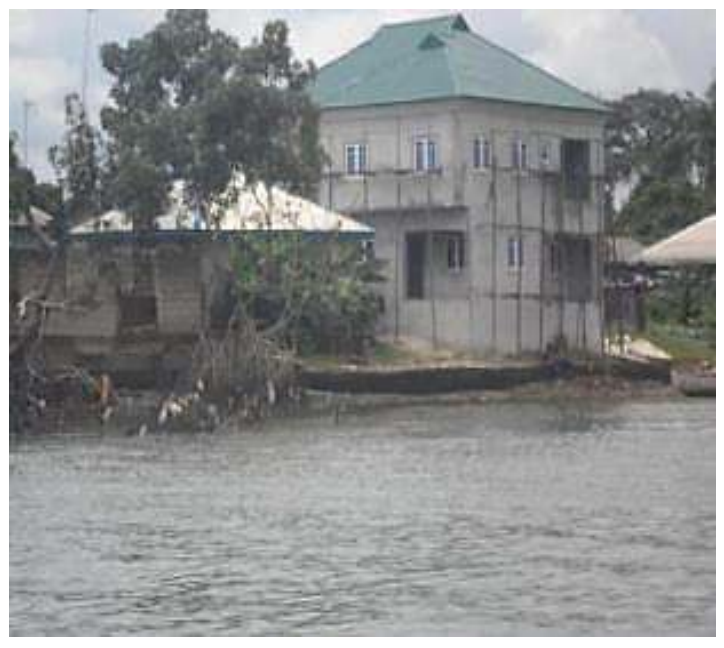

Plate 3. Showing residential property at the shore evidence of cheap and available construction sand Source: Authors' field survey, 2016

Besides these positive perception and benefits derived from mining of sand and its derivatives, there are also some negative perceptions and consequences of this practice.

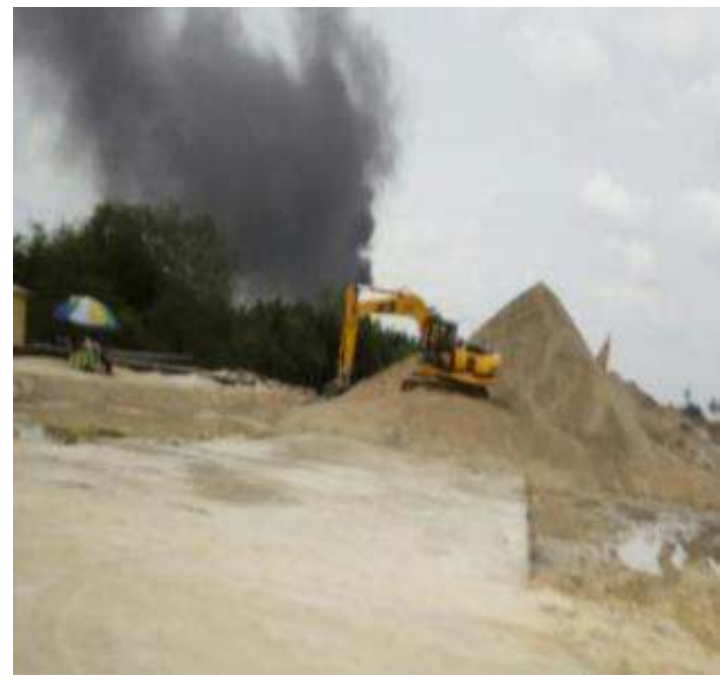

Plate 4. Thick smoke from sand dredgers polluting the environment

Source: Authors' field survey, 2016

From the pictorial evidence, as against the ratings of the respondents, it was evident that the short lived pecuniary accruals and the level of economic deprivation coloured their perception. They tend to forget the dangers inherent in the degradation of the environment with its long-term effect on those whose livelihood depends on the environment.

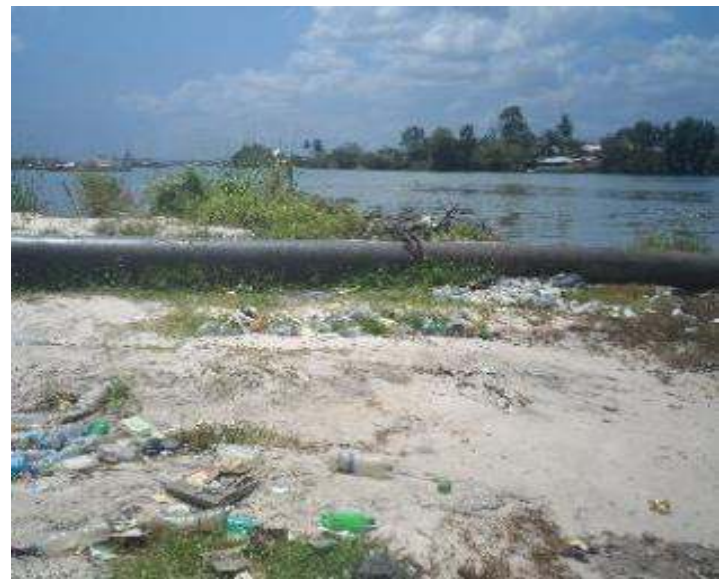

Plate 5. Picture showing accumulated debris Source: Authors' field survey, 2016

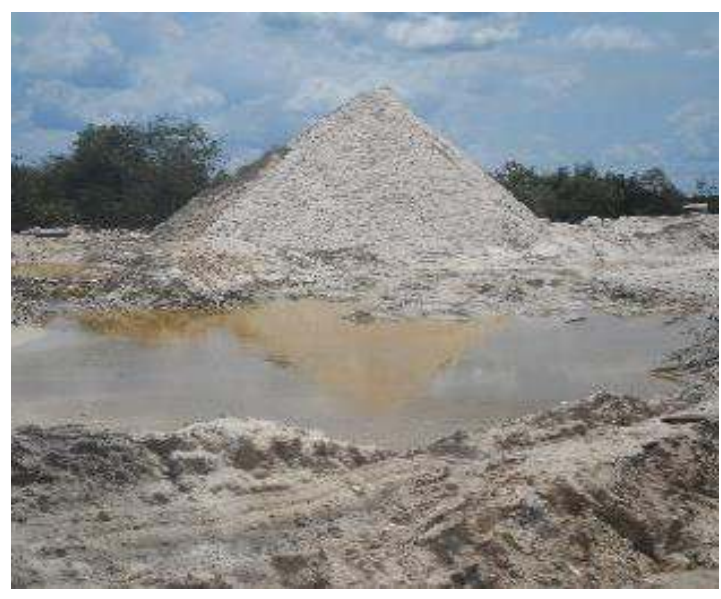

Plate 6. Picture showing artificial pond caused by dredging

Source: Authors' field survey, 2016

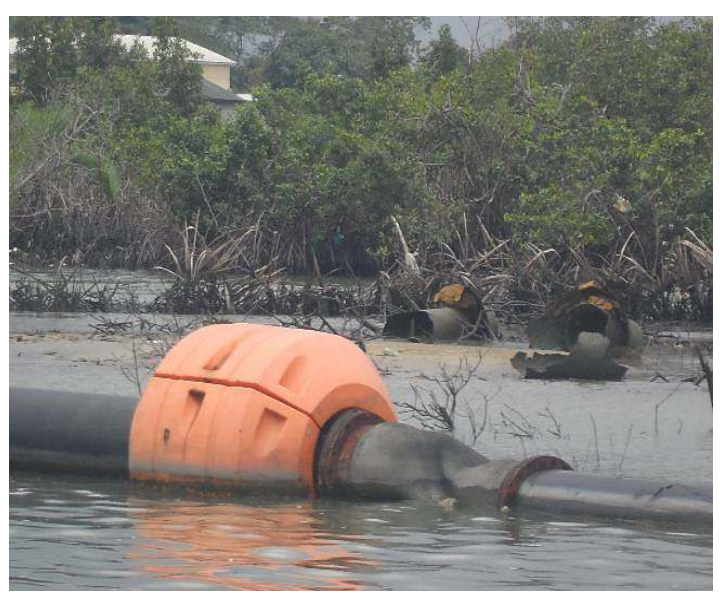

Plate 7. Picture showing damaged riparian vegetation

Source: Authors' field survey, 2016 
Table 4. Respondents negative views of sand mining

\begin{tabular}{|c|c|c|}
\hline $\mathbf{S} / \mathbf{N}$ & Respondents views & $\%$ \\
\hline 1 & $\begin{array}{l}\text { Depressions are left uncovered after decommissioning of mining sites causing water to } \\
\text { collect in them and become unsafe for livestock, humans and turns breeding ground } \\
\text { for mosquitoes and other vectors. }\end{array}$ & 13 \\
\hline 2 & $\begin{array}{l}\text { Upsurge of criminal activities with the } \\
\text { influx of youths foraging the neighbourhood to eke a living by day and resort to pilfering } \\
\text { at night; }\end{array}$ & 5 \\
\hline 3 & Vegetation and grazing land are destroyed through soil erosion; & 19 \\
\hline 4 & $\begin{array}{l}\text { Livestock not watered adequately due to shortage and distortion of recreational } \\
\text { activities like swimming and fishing; }\end{array}$ & 7 \\
\hline 5 & $\begin{array}{l}\text { It leads to air pollution and sometimes causes cracks on building due machine } \\
\text { pollutions and trucks movements; }\end{array}$ & 8 \\
\hline 6 & Most paved roads are destroyed by heavy duty trucks; & 5 \\
\hline 7 & Mining deepens rivers and widens river banks; & 3 \\
\hline 8 & It generally destroys the environment; & 22 \\
\hline 9 & Car windscreen are damaged due uncovered transported sand; & 2 \\
\hline 10 & $\begin{array}{l}\text { There are cases of soil subsidence around river banks are commonly evidenced } \\
\text { around mining site; }\end{array}$ & 16 \\
\hline & Total & 100 \\
\hline
\end{tabular}

Source: Authors' field survey, 2016

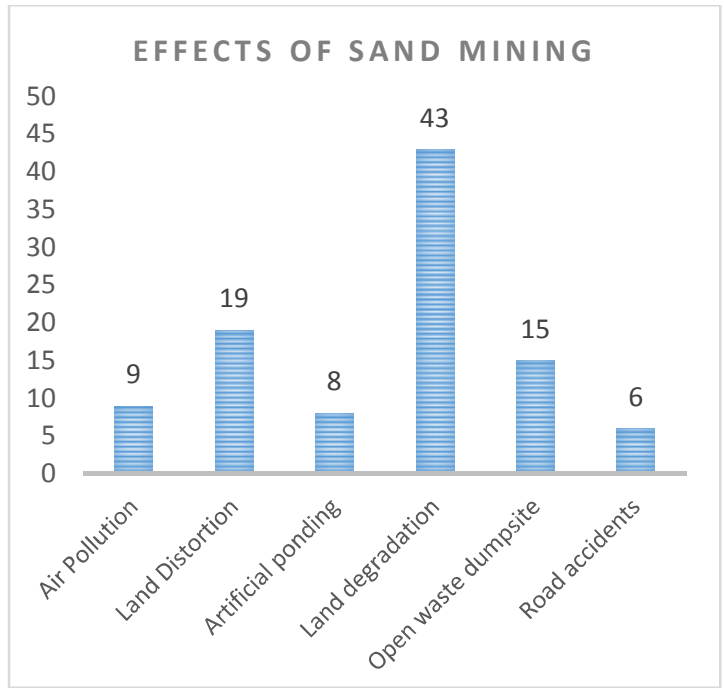

Fig. 1. Perceived effects of sand mining Source: Authors' field survey, 2016

\subsubsection{Identification of the impacts of sand mining within the communities}

Natural resource extraction in a holistic phenomenon that leaves behind its trail myriads of negative and positive environmental conditions.

During this study the impacts were identified and qualified initiated on the effect of the hazard on the social sensitivities as specified and classified with attributes:
1. Positive or negative;

2. Direct or indirect;

3. Short term/temporary or longterm/permanent;

4. Reversible or irreversible

5. Phase of occurrence (mobilization, construction, operations, decommissioning and abandonment);

6. Local and/or regional, and/or national, and/or global;

7. Incremental/Non-incremental

8. Nature of the source of hazard;

9. Sensitivity of the receiving environment (receptor);

10. Existence of a pathway between the source and the receptor.

The social sensitivities indicate the detailed characteristics of the social environment which once disturbed, culminates into the distortion of the environmental stability.

Some identified indicators of social sensitivities that were applicable in this study include the following:

1. Patterns of traditional occupation

2. Levels of incomes and financial flows

3. Cost of living/ inflation

4. Opportunities for contracting and procurement

5. Job opportunities for locals

6. Access to housing

7. Access to transport 
8. Access to roads and water ways

9. Access to electricity

10. Access to communication facilities

11. Access to educational facilities

12. Access to recreational facilities

13. Access to sanitation and waste management

14. Balance in gender

15. Functioning of family structure

16. A safe and secure living environment

17. Respect for labour rights

18. Promotion of equal opportunity

19. Promotion of opportunities for representation

20. Social exclusion abetment

21. Poverty level

22. Moral and family values

23. Language and Cultural values

24. Traditional and/or Religious structures and customs

Based on the above, some of the indicators of social sensitivities with major and moderate impacts that were evident due to sand extraction in the communities are as follows:

1. Reduction in levels of income and financial flows (Major)

2. Rise in level of poverty (Major)

3. Variation in patterns of traditional occupations (Major)

4. Alteration in the access to transportation (major)

5. Alteration in the access to water ways (major)

6. Variation in access to housing (moderate)

7. Rise in cost of living and inflation rate (major)

8. Changes in the safety and security of the environment (major)

9. Changes to recreational pattern (major)

10. Change in cultural values and languages (moderate)

Some positive effects of sand mining in the communities are:

Opening for procurement and contracting for the locals (moderate)

Opening for employment for mostly the locals (major).

\subsubsection{Social consequences of sand mining}

The social consequences of sand mining in the study area has been highlighted. There were changes in the:
1. Access to housing (moderate)

2. Patterns of traditional occupations (major)

3. Cultural values and languages (moderate)

4. Recreational facilities (major)

5. Access to housing (moderate)

6. Security and safety of the immediate environment (major)

\subsubsection{Economic consequences and benefits of sand mining}

There are some identified negative economic consequences of sand mining in the study:
Alteration in access to water ways (Major)
Rise in cost of living/inflation rate (Major)
Alteration in access to transportation (Major)
Alteration in access to water ways (Major)
Reduction in levels of income and financial flows (Major)
Rise in level of poverty (Major)

These identified social sensitivities and their consequences which has altered the livelihood chain of these riparian communities and has caused the community members to depend on others sources of livelihood other than their traditional means of sustenance.

\subsubsection{Mitigation measures for identified negative impacts and enhancement measures for positive ones}

The extraction of natural resources like river sand and its derivatives in every society is plagued with negative and positive consequences on the environment, humans, and the riparian ecosystem. The major fallout of this is the disruption and distortion of the livelihood chain that exist for those relying on that for their survival.

However, amid these negative and positive consequences occasioned by natural resource extraction on the environment, there is the need to put in place effective mitigation measures to alleviate the negative challenges posed by the extraction of natural resources on the environment. Thus, this study highlights some mitigation measures for all concern based on the distortions and destruction of the environment.

\subsubsection{Negative impacts (Moderate and Major)}

\subsubsection{Change in patterns of traditional occupations (Major)}

The host communities of these mining sites are agrarian and riparian in nature and it has 
been their sources of livelihood over the years but with the emergence of sand extraction activities, the people are forced to gradually adjust to changes in their traditional occupations occasioned by the presence of sand miners. This is a major impact in the natural resource extraction livelihood chains within the environment.

\subsubsection{Reduction in levels of income and financial flows (Major)}

As sand extraction progresses, there is the tendency of reduced cash inflows to the community members. This a direct consequence of the destruction of livelihood sources by miners of sand and its derivatives. This also due to challenges posed by occupational readjustments by the affected natives.

\subsubsection{Rise in cost of living/inflation rate (Moderate)}

With the influx of people especially sand miners and their cohorts, they tend to stimulate the local economy and outbid the locals in almost all spheres of the communal living. Thus, the local economy experiences traces of inflation and cost of living.

\subsubsection{Rise in level of poverty (Major)}

The unsustainable resource extraction practice in Nigeria has given room to loss of rural livelihoods leading to job losses, reduced crop yields, fish catch and reduced income. This most times increases the poverty level as purchasing power has dwindled over time.

\subsubsection{Variation in the access to housing (Moderate)}

As the extraction of sand and its derivatives in the community progresses, all those involved in the value chain: truck drivers, workers, business oriented individuals and miners alike are expected to be housed within their area of operation. With this trend, there is bound to be pressure on the existing housing stock making access to housing difficulty pending the duration of occupation of these houses.

Table 5. Mitigation measures for identified negative impacts

\begin{tabular}{|c|c|c|c|c|}
\hline $\mathbf{S} / \mathbf{N}$ & Impact description & $\begin{array}{l}\text { Gross } \\
\text { rating }\end{array}$ & Mitigation & $\begin{array}{l}\text { Net } \\
\text { rating }\end{array}$ \\
\hline \multicolumn{5}{|c|}{ Mitigation measures } \\
\hline 1. & $\begin{array}{l}\text { Change in patterns of } \\
\text { traditional occupation }\end{array}$ & Major & $\begin{array}{l}\text { Payment of compensation commensurate } \\
\text { to the land taken to facilitate occupational } \\
\text { adjustment of the natives }\end{array}$ & Minor \\
\hline 2. & Rise in level of poverty & Major & $\begin{array}{l}\text { Create employment prospects and skills } \\
\text { acquisition schemes. }\end{array}$ & Minor \\
\hline 3. & $\begin{array}{l}\text { Rise in the cost of living } \\
\text { and inflation rate }\end{array}$ & Moderate & $\begin{array}{l}\text { Creation of jobs to improve other income } \\
\text { streams }\end{array}$ & Minor \\
\hline 4. & $\begin{array}{l}\text { Reduction in level of } \\
\text { income and financial flow }\end{array}$ & Major & $\begin{array}{l}\text { Improve on available sources of } \\
\text { livelihood with the provision of grants and } \\
\text { aids to natives }\end{array}$ & Minor \\
\hline 5. & $\begin{array}{l}\text { Variation in the access to } \\
\text { Housing }\end{array}$ & Major & $\begin{array}{l}\text { Provision of mortgage financing and } \\
\text { affordable housing units for the natives. }\end{array}$ & Minor \\
\hline 6. & $\begin{array}{l}\text { Change in access to } \\
\text { transportation }\end{array}$ & Major & $\begin{array}{l}\text { Provide alternative transportation routes } \\
\text { away from hazards associated with } \\
\text { dredging pipeline }\end{array}$ & Minor \\
\hline 7. & $\begin{array}{l}\text { Alteration in the access to } \\
\text { waterways }\end{array}$ & Major & $\begin{array}{l}\text { Provide alternative routes to ease } \\
\text { movement around }\end{array}$ & Minor \\
\hline 8. & $\begin{array}{l}\text { Change in the safety and } \\
\text { security of living } \\
\text { environment }\end{array}$ & Major & $\begin{array}{l}\text { Provision of community based security to } \\
\text { guard the residents }\end{array}$ & Minor \\
\hline 9 & $\begin{array}{l}\text { Changes in access to } \\
\text { recreational facilities }\end{array}$ & Moderate & $\begin{array}{l}\text { Provide additional recreational amenities } \\
\text { to balance existing ones. }\end{array}$ & Negligible \\
\hline 10. & $\begin{array}{l}\text { Change in cultural values, } \\
\text { w } \backslash \text { traditional structure and } \\
\text { custom }\end{array}$ & Moderate & $\begin{array}{l}\text { Reverence and esteem for the belief } \\
\text { systems, the culture language of the } \\
\text { people. }\end{array}$ & Negligible \\
\hline
\end{tabular}




\subsubsection{Change in access to transportation (Major)}

Haulage of products is one of the most challenging aspect of natural resource extraction in the study area because as the trucks progressively haul sand to their respective endusers. There is pressure on the road infrastructure which was not designed for such load causing the roads to fail with time and inconveniencing other road users with smaller vehicles.

\subsubsection{Change in access to waterways (Major)}

The practice of sand extraction in Nigeria when operational often reduces accessibility around the waterways. This is fallout of network of sand pipes traversing the river ways which impede free movement of fisher folks and others whose livelihood revolves around the river. Others are those who use the river as a recreational site are forced to look for alternative means of livelihood.

\subsubsection{Change in safety and security of environment (Major)}

During the mining of sand and its derivatives there is bound to be the influx of all shades and manner of people with both good and criminal intent around the neighbourhood. This migratory trend leads to increase in crime, social vices and related negative activities like prostitution and spread of sexually transmitted diseases with the environment. This has major impact on the people as it is alien to their socio-cultural orientation being a relatively conservative society.

\subsubsection{Changes in access to recreational facilities (Moderate)}

Wetlands is a valuable resource in recreation of community members who embark in water sports, but with the emergence sand miners in the neighbourhood all these are destroyed and/or distorted.

\subsubsection{Change in family values and morals (Moderate)}

Family ties are on the brink of near extinction or failure because all the people involved in the process have divergent views and cultural background and children and adult alike tend to copy new lifestyles exhibited to them. This action with time erodes the family ties and downplays morals.
It is worthy of note that these changes in these communities have been progressively incremental over the years and culminated into disordered situation where the perceived shortterm accruals have coloured their value system and sense of judgement, with no regards for sustainable resource extraction within their communities.

There are key components of these changes identified that needs to be enhanced and the measures for such enhancement is proposed in Table 6.

Some of the community members have decried the practice within the community because in some cases the permits for extraction are given to miners without due consultation with the community members as asserted by a resident in the affected community:

"...you see this nonsense (mining) opposite my house started in 2005 when a small area was given off by the host community (Nkpolu-Orowurukwo). This activity became uncontrollable at a very large scale that passage to my house is now a difficult task, the access road to my house and other houses on this street is in a very deplorable condition, noise and pollution all the time that one cannot have a good afternoon or weekend rest. The issue had been reported to relevant responsible authorities at both Community and Government levels to no avail, so we have left our destiny in the hands of God" (Chief Emeka (resident), September, 2016).

Another dimension to this menace of uncontrolled sand mining trend is where the actual owners of the portion of land ceded for sand mining do not reside within the impact zone and benefit from the activities but the impact is felt by adjoining communities. Due information not given to the impacted communities as asserted by a chief from one of the communities (Mgbuodohia). Thus:

"...there were no consultations between us and our sister community the NkpoluOroworukwu on what they wanted to do since we share the river in almost everything about it, all we saw one day was people bringing in machines which we found out to be dredgers for sand. We tried to call their attention but nothing happened we went to the government, no response; so, we left it to 
God. Today we are suffering from the consequences of their actions while they benefit from the revenues and other attendant benefits from the sand mining activities"- Community chief in Mgbuodohia community (Source: Author's Field Survey, September, 2016).

This is the consequence of failure of not engaging the public before commencement of any project by both government and host communities. This has been the true situation in Rivers State over the years and has become a norm that communities and government alike don't have regards for extant laws governing natural resource extraction.

One of such law is the Environmental Impact Assessment Decree No. 86 of 1992, which sets out the guidelines and procedures prior commencement of certain public or private projects.

The specific objectives of the EIA Act are:

I. To consider prior commencement of any project or activity, the probable impacts and degree of these impacts on the environment;

II. To promote the implementation of appropriate policy in all Federal Lands consistent with the laws and decision making processes through which the goal of the Act may be realized; and

III. To encourage the development of procedures for information exchange, notification and consultation between organizations and persons when the proposed activities are likely to have significant environmental effects on boundary or trans-state or on the environment of bordering towns and villages.

Also, the National Inland Waterways Law No. 13 of 1997 empowers National Inland Waterway Authority (NIWA) to:

I. Undertake capital and maintenance dredging

II. Undertake hydrological and hydrographic surveys

III. Subject to the provisions of Environmental Impact Assessment of Navigation and other dredging activities within the inland water and its rights - of - way.

IV. Grant permit and licenses for sand dredging, pipeline construction, dredging of slot and crossing water ways by utility lines, water intake, rock blasting and removal.

V. Approve and control all reclamation of land within the right of way, survey, remove and receive derelicts, wrecks and other obstruction from inland water ways.

From the available data and participant observation, these extant laws that control natural resource extraction and guidelines stipulated by these laws seem are not adhered to by those involved in natural resource extraction especially in sand mining.

The practice of natural resource extraction is a driving force for economic development globally and the Nigerian state is not an exception in this trend. However, the practice of natural resource extraction in Nigeria especially in Rivers State has metamorphosed into teething troubles between the government and the owners of these resources due to the approaches adopted by all parties involved.

Table 6. Enhancement measures for identified key changes

\begin{tabular}{lllll}
\hline S/N & Impact description & $\begin{array}{l}\text { Gross } \\
\text { rating }\end{array}$ & Mitigation & $\begin{array}{l}\text { Net } \\
\text { rating }\end{array}$ \\
\hline $\begin{array}{l}\text { Enhancement Measures } \\
\text { 1. } \begin{array}{l}\text { Change in patterns of } \\
\text { traditional occupation }\end{array}\end{array}$ & Major & $\begin{array}{l}\text { Payment of compensation commensurate } \\
\text { to the land taken to facilitate occupational } \\
\text { adjustment of the natives } \\
\text { Create employment prospects and skills } \\
\text { acquisition schemes. }\end{array}$ & Minor \\
2. & Rise in level of poverty & Major & $\begin{array}{l}\text { Creation of jobs to improve other income } \\
\text { streams }\end{array}$ & Minor \\
3. $\quad \begin{array}{l}\text { Rise in the cost of living } \\
\text { and inflation rate }\end{array}$ & Moderate & Source: Authors' field survey, 2016 &
\end{tabular}


The implication of these failures from the government agencies saddled with these responsibilities as regulators and communities who play host to these miners have resulted in a lawless chaotic environment, where there are little or no remediation and regeneration programs in place for destroyed and/or distorted ecosystem and biodiversity loss occasioned by continuous uncontrolled mining of sand.

\section{CONCLUSION}

The practice of natural resource extraction which includes mining of sand and its derivatives is a viable economic endeavour that drives development and generate income streams for all tiers of government, communities and individuals alike. However, this phenomenon has witnessed a repudiation of the tenets of sustainable resource extraction in recent times especially within the Victory River precinct of Rivers State, Nigeria. The trend has been the continuous uncontrolled extraction of sand and its derivatives which had led to destruction of the ecosystem, distortion of the livelihood chain and subsequent biodiversity loss.

Although the study found out that there are social and economic accruals of sand mining to all involved in the value chain, but they are shorttermed because the dynamics of negative social and economic changes elicited by these actors are in most situations irreversible on the environment and the collective psyche of the people in the impacted communities.

It is imperative to assert that there is the need to adopt global best practices to encourage sustainable resource extraction, enforcement and compliance to extant laws of Nigeria dealing with resource extraction and implement sustainable mitigation measures to reduce the negative impacts on the environment and the people in combination with effective social management plan.

\section{RECOMMENDATIONS}

The study recommends tripartite approach to this phenomenon which includes; policy and decision makers directly involved in management and control of natural resource extraction, the miners and the community.

\subsection{Policy and Decision Makers}

i. The Environmental Impact Assessment (EIA) study as stipulated by the provisions of Decree No. 86 of 1992 should been done by registered relevant professionals who could be assessed with relative ease for further details and clarifications of grey areas that may arise in the report.

ii. There should be a coordinated approach as regards effective decision-making process among stakeholders with respect to mitigating all identified potential risk to the environment as a result of sand mining activities;

iii. There should be effective control of sand mining activities within the state with respect to operational time, proper signs informing people of the presence of sand dredgers to discourage unnecessary activities and/or accidents around mining sites.

iv. Buffers like embankments should be constructed to reduce the menace of flooding of the shorelines and destruction of adjoining properties.

v. There should be elaborate public enlightenment programmes from the Ministries of Environment, Information and the National Orientation Agency to regularly educate the public and miners about the adverse effects of continuous uncontrolled mining in the study area.

vi. There should be consistent but periodic engagements and consultations with impacted communities with respect to their involvements in mining activities.

\subsection{Miners}

i. Miners should show evidence and adopt Sustainable Environmental Management Plan (SEMPlan) which should be a prerequisite for mining permit;

ii. There should be in place an effective public participation mechanism to address the views of all concerned in the environment especially community members, government and the mining companies before commencement of mining operations.

iii. There should be in place proper restoration plan for decommissioned mining sites, alternate mining sites to reduce pressures and challenges associated with continuous uncontrolled sand extraction in the study area.

iv. There should be adequate setbacks observed between the loading bay and the river bank to reduce incidents of damage to the river banks and residential properties. 
v. The local government should enforce compliance and ensure that trucks loaded with sand, as a precondition must be properly covered to minimize damages trailing vehicles caused by drops of sand grains during conveyance.

\subsection{Community}

I. Issuance of mining rights by the community should be discouraged or stopped completely to enable government monitor the activities of miners.

ii. Communities should adopt public participation to hear the fears and concerns of most of the inhabitants before giving local mining leases.

iii. There should be community based environmental monitoring and management committee manned by professionals to check the activities of sand mining companies and those giving leases for such.

\section{COMPETING INTERESTS}

Authors have declared that no competing interests exist.

\section{REFERENCES}

1. Kondolf GM. Geomorphic and environmental effects of instream gravel mining. Landscape and Urban Planning. 1994;28(2-3):225-243.

2. Padmalal D, Maya K, Sreebha S, Sreeja R. Environmental effects of river sand mining: A case from the river catchments of VembVnad lake, southwest coast of India. Environmental Geology. 2008;54(4):879889.

3. Saviour MN. Environmental impact of soil and sand mining: A review. International Journal of Science. Environment and Technology. 2012;1(3):125-134.
4. Mwangi S. Management of River Systems in East Africa. Nairobi: Macmillan; 2007.

5. Goddard J. Land degradation and rehabilitation; 2007.

6. Draggan S. Encyclopedia of earth sand and gravel. Washington DC; 2008.

7. Stebbins M. Can gravel mining and water supply wells co-exist. Maine: University of Maine; 2006.

8. Kuttipuran M. RIVERS: Physical modifications. Singapore: Donnelley; 2006.

9. Lawal P. Effects of sand/gravel mining in Minna Emirate area of Nigeria on stakeholders. Journal of Sustainable Development. 2011;4(1);193.

10. Aromolaran A. Effects of sand winning activities on land in agrarian communities of Ogun state, Nigeria. Continental Journal of Agricultural Science. 2012;6(1):41-49.

11. Hill L, Kleynrans C. Authorization and licensing of sand mining/gravel extraction, in terms of impacts on in-stream and riparian habitats. Journal of Mining Science. 1999; 15:17-19.

12. Lupande F. Zimbabwe: The high cost of sand. The Herald. 2012;34(8).

13. Mbaiwa KA. Handbook of socio economic and environmental impacts of mining and development. Gaborone: Macmillan; 2008.

14. Schaetzl R. Sand and gravel mining for aggregate; 1990.

Available:https://www.msu.edu/-soils (Accessed on the $10^{\text {th }}$ November, 2016)

15. Madyise T. Case studies of environmental impacts of sand mining and gravel extraction for urban development in Gaborone; 2013.

16. Bagchi P. Unregulated Sand Mining Threatens Indian Rivers. The Journal India Together. 2010; $21: 7-9$

17. Pereira K. Illegal sand mining: The unexamined threat to water security in India; 2012.

Available:http/www.ismeenvisnic.in (Accessed on the $10^{\text {th }}$ November 2016)

(0) 2017 Johnbull and Brown; This is an Open Access article distributed under the terms of the Creative Commons Attribution License (http://creativecommons.org/licenses/by/4.0), which permits unrestricted use, distribution, and reproduction in any medium, provided the original work is properly cited.

Peer-review history:

The peer review history for this paper can be accessed here: http://sciencedomain.org/review-history/19793 